\title{
A STUDY OF LIPID PROFILE, BMI, PREHYPERTENSION AND INTIMA MEDIA THICKNESS IN MEDICAL STUDENTS OF COASTAL ANDHRA PRADESH
}

\author{
D. Shakeela1 , P. Raja Babu²
}

${ }_{1}^{1}$ Associate Professor, Department of Physiology, Rangaraya Medical College, Kakinada.

${ }^{2}$ Associate Professor, Department of Physiology, ACSR Government Medical College, Nellore.

\section{ABSTRACT}

With the development of effective drugs and best health care system, vaccination and healthy life style the death rate due to infectious disease has decreased globally and is replaced by NCD (Non-Communicable Disease). Sixty medical student were selected for study as per inclusion and exclusion criteria with proper approval from institutional ethics committee and various parameter were measured. Early intervention, lifestyle modification, weight control, increasing physical activity, diet modification can prevent the progress of disease.

\section{KEYWORDS}

Dyslipidemia, Prehypertension, Intima Media Thickness.

HOW TO CITE THIS ARTICLE: D. Shakeela, P. Raja Babu. "A Study of Lipid Profile, BMI, Prehypertension and Intima Media Thickness in Medical Students of Coastal Andhra Pradesh." Journal of Evolution of Medical and Dental Sciences 2015; Vol. 4, Issue 101, December 17; Page: 16680-16682, DOI: 10.14260/jemds/2015/2491

\section{INTRODUCTION}

With the development of effective drugs and best health care system, vaccination and healthy life style the death rate due to infectious disease has decreased globally and is replaced by NCD (Non-Communicable Disease). As per WHO 2012 data 38 million death was alone due to NCD globally (5.6 million in India) $48 \%$ of these deaths in low and middle income country.(1) Important point about this is that $80 \%$ of the premature heart disease, stroke and diabetes can be prevented. Usually, NCD are associated with older age group but evidence shows that 16 million of all death is between 30 70 years of age, which is premature death. Children, adult and the elderly all are vulnerable to the risk factor that contributes to the NCD. These diseases are driven by modifiable risk factor like tobacco, physical inactivity, alcohol, excess salt and sodium intake. These behaviours lead to certain metabolic changes like hypertension, dyslipidemia, hyperglycaemia and obesity. These all factors are modifiable and this premature death can be prevented.(1,2,3) Prehypertension has been defined as systolic BP 120 to 139 or diastolic BP 80 to $89 \mathrm{mmHg}$ (4); it used to increase in severity with time. The risk ratio of dyslipidemia, obesity, metabolic syndrome and diabetes mellitus are greater in prehypertensive and it is associated with increased risk of cardiovascular disease. $(5,6,7,8)$

\section{MATERIAL AND METHOD}

This is a prospective study to evaluate the existence of cardiovascular risk factor and markers of atherosclerosis like pre-hypertension, dyslipidemia and BMI and intima-media thickening in medical student in Coastal Andhra Pradesh. Before start of study permission from institutional ethics committee was obtained and written consent was taken from each student on prescribed consent form.

Financial or Other, Competing Interest: None.

Submission 01-12-2015, Peer Review 02-12-2015,

Acceptance 11-12-2015, Published 17-12-2015.

Corresponding Author:

Dr. D. Shakeela,

15-13-16/2, Akruti Annapurna Residency,

Krishna Nagar, M. R. Peta,

Visakhapatnam, Andhra Pradesh.

E-mail:janakibabu@yahoo.com

DOI:10.14260/jemds/2015/2491
Sixty students were enrolled for study as per inclusion and exclusion criteria. Inclusion criteria was Age:- Between 18-28 years, Sex - Both Exclusion criteria was Diabetes, Hypertension, Kidney and Liver Diseases taking any kind of medication for chronic diseases. Various parameters were calculated like body weight in kilogram, height in meters, waist circumference, hip circumference, family history of DM and hypertension was obtained.

For blood pressure measurement, the participant were allowed to rest quietly for at least $5 \mathrm{~min}$. Three times blood pressure was measured at $2 \mathrm{~min}$ interval by sphygmomanometer. The first and fifth Korotkoff sounds were recorded as SBP and DBP. BP classification was based on reconditions from (Joint National Committee) 7.(5)

For criteria of optimal concentration of serum lipid concentration, we followed American Association of Clinical Endocrinologist Guidelines.(9) LDL concentration below $<110 \mathrm{mg} / \mathrm{dl}$ was considered to be acceptable $<110-129$ borderline and above $>130 \mathrm{mg} / \mathrm{dl}$ was considered to be high $\mathrm{HDL}-\mathrm{C}>60 \mathrm{mg} / \mathrm{dl}$ considered negative risk factor, borderline 40-59 (Men) and 50-59 (Female) and less than 40 in male and 50 female is considered high risk. TG-c less than 150 is normal between 150-199 borderline and above 200 high LDL-c was estimated by WT Friedowald, RI Lery and DC Friedrickson method, serum triglycerides estimated by method of Neri and Fringe 1973 modified Debnath 1978. HDL estimated by precipitation method and Intima-media thickness was estimated by Philips ClearVue USG machine.

\section{RESULT}

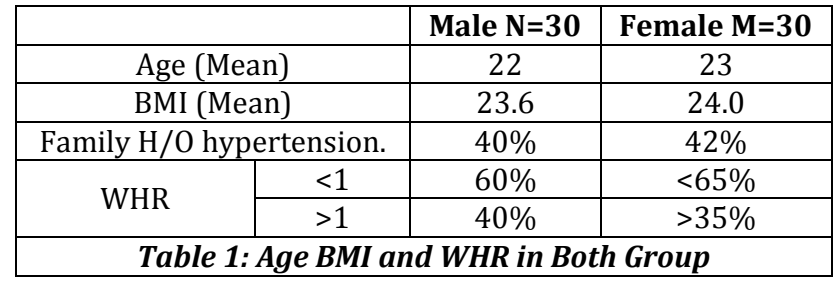

In this study, as per Table 1 it is clear that mean age of male student was 22 years and female was 23 yrs. Mean of body of mass index for male student was 23.6 and for female student it was $24 ; 40 \%$ of the male student has family history of hypertension and $42 \%$ of the female students have family history of hypertension. 


\begin{tabular}{|c|c|c|c|}
\hline \multicolumn{4}{|c|}{ Pre-Hypertensive and Normotensive } \\
\hline Age & (18 to 20 yrs.) & $20 \%$ & $80 \%$ \\
\hline & $>20 \mathrm{yrs}$ & $30 \%$ & $70 \%$ \\
\hline Sex & Male & $40 \%$ & $60 \%$ \\
\hline & Female & $34 \%$ & $66 \%$ \\
\hline & Family History & $64 \%$ & $10 \%$ \\
\hline
\end{tabular}

From Table 2, it is clear that in our study between ages 18 to 20 year $20 \%$ of student were pre hypertensive and above 20 year of age $30 \%$ of the students were pre hypertensive; $40 \%$ of the male were pre hypertensive and $36 \%$ of the female were pre hypertensive; $64 \%$ of the prehypertensive students have family history of hypertension but only $10 \%$ of the normotensive have family history of hypertension

\begin{tabular}{|c|c|c|c|}
\hline & \multicolumn{2}{|c|}{ Male (N=30) } & Female (N=30) \\
\hline \multirow{3}{*}{ LDL - C } & $\mathrm{N}$ & 12 & 14 \\
\cline { 2 - 4 } & $\mathrm{B}$ & 16 & 14 \\
\cline { 2 - 4 } & $\mathrm{H}$ & 2 & 2 \\
\hline \multirow{3}{*}{ HDL - C } & $\mathrm{N}$ & 10 & 8 \\
\cline { 2 - 4 } & $\mathrm{B}$ & 12 & 10 \\
\hline \multirow{3}{*}{ TG - C } & $\mathrm{Low}$ & 8 & 12 \\
\cline { 2 - 4 } & $\mathrm{N}$ & 10 & 12 \\
\cline { 2 - 4 } & $\mathrm{B}$ & 18 & 14 \\
\hline \multicolumn{3}{|c|}{ Table 3: Dyslipidemia in Both the Group } \\
\hline
\end{tabular}

\section{(N=NORMAL, B=BORDERLINE AND H=HIGH)}

Among 30 male students two students have LDL - C high range and 16 have borderline. In female students, 2 have high LDL - C concentration and 14 hours borderline. HDL - C was very low in 8 male and 12 female students. Similarly TG was very high in 2 male and 4 female students 18 and 14 male and female student have borderline TG-C respectively.

\begin{tabular}{|c|c|c|c|}
\hline & \multicolumn{2}{|c|}{ Male (N=12) } & Female (N=11) \\
\hline \multirow{3}{*}{ LDL - C } & $\mathrm{N}$ & 2 & 1 \\
\cline { 2 - 4 } & $\mathrm{B}$ & 8 & 7 \\
\cline { 2 - 4 } & $\mathrm{H}$ & 2 & 2 \\
\hline \multirow{3}{*}{ HDL - C } & $\mathrm{N}$ & 2 & 2 \\
\cline { 2 - 4 } & $\mathrm{B}$ & 2 & 0 \\
\cline { 2 - 4 } & $\mathrm{Low}$ & 8 & 9 \\
\hline \multirow{3}{*}{ TG - C } & $\mathrm{N}$ & 2 & 1 \\
\cline { 2 - 4 } & $\mathrm{B}$ & 7 & 6 \\
\cline { 2 - 4 } & $\mathrm{H}$ & 2 & 4 \\
\hline & \multicolumn{3}{|c|}{ Table 4: Dyslipidemia in relation to Pre-Hypertension } \\
\hline
\end{tabular}

Regarding relation of Dyslipidemia with prehypertensive student. Out of 12 pre-hypertensive students, 10 have LDL-C above normal in male and 10 students have HDL-C below normal, and 9 have TG above normal level. Similar resent was formed in female also.

\begin{tabular}{|c|c|c|c|}
\hline SEX & \multicolumn{3}{|c|}{ Intima Media Thickness in mm } \\
\hline \multirow{2}{*}{ Male $(\mathrm{N}=30)$} & 39 to 0.45 & 0.45 to 0.5 & $>0.5$ \\
\cline { 2 - 4 } & 12 & 17 & 1 \\
\hline Female (N=30) & 18 & 12 & 0 \\
\hline \multicolumn{2}{|c|}{ Table 5: Intima-Media Thickness in Both Sexes } \\
\hline
\end{tabular}

\section{Intima-Media Thickness}

Almost all the students, both male and female has intimamedia thickness below $0.50 \mathrm{~mm}$, which is in normal range for that age group.

\section{DISCUSSION}

Pre-hypertension as per JNC 7 report is considered as the potential risk of hypertension and CV disease.(10) As per other studies, increase in blood pressure above normal is associated with accelerated hypertension. In our study, the prevalence of pre-hypertension was $40 \%$ in male students and $34 \%$ in female students, which is similar to the study of Debbarma et al., Mohit Shali et al.(12,13,14)

As per our study, it is observed that among prehypertensive students, $64 \%$ of them have family history of hypertension and among normotensive students it was $10 \%$ which is same as per study of Wu JS and Lu FH et al.(15,16) WHR was found to be normal in $60 \%$ of the male and $65 \%$ of the female students, which was similar to the study of other authors.(17)

In our study, it is found that in pre-hypertensive patients LDL-C was borderline in $70 \%$ of male and $70 \%$ of female and in $20 \%$ of then it was high. Similarly, HDL-C was low in $80 \%$ of both male and female students and TG-C was also either borderline or high in $80 \%$ of the student, which is similar to the work of others. ${ }^{(18,19)}$ Intima media thickness was normal in both the sexes. It was less than $0.5 \mathrm{~mm}$, which is normal for both sexes.

\section{CONCLUSION}

Non-communicable diseases incidence is increasing and it is the major cause of premature death. Prevalence of dyslipidemia and prehypertension remains a more frequent undetected health problem in early age. So early intervention, lifestyle modification, weight control, increasing physical activity, diet modification can prevent the progress of disease.

\section{BIBLIOGRAPHY}

1. World Health Organisation. Non-communicable diseases fact sheet updated January 2015.

2. Lim SS, Vos T, Flaxman AD, Danaei G, Shibuya K, AdairRohani $\mathrm{H}$, et al. A comparative risk assessment of burden of disease and injury attributable to 67 risk factors and risk factor clusters in 21 regions, 1990 2010: a systematic analysis for the Global Burden of Disease Study 2010. Lancet, 2012;380(9859):22242260.

3. Mozaffarian D, Fahimi S, Singh GM, Micha R, Khatibzadeh S, Engell RE, et al.; Global Burden of Diseases Nutrition and Chronic Diseases Expert Group. Global sodium consumption and death from cardiovascular causes. N Engl J Med 2014;371(7):624-34. doi:10.1056/NEJMoa1304127.

4. Paul A James, MD; Suzanne Oparil, MD; Barry L Carter, PharmD; William C Cushman, MD; Cheryl DennisonHimmelfarb, RN, ANP, PhD; Joel Handler, MD; et al. 2014 Evidence-Based Guideline for the Management of High Blood Pressure in Adults Report from the Panel Members Appointed to the Eighth Joint National Committee (JNC 8).

5. Chobanian AV, Bakris GL, Black HR, Cushman WC, Green LA, Izzo JL Jr; Joint National Committee on Prevention, Detection, Evaluation and Treatment of High Blood Pressure. National Heart, Lung and Blood Institute; National High Blood Pressure Education Program Coordinating Committee. Seventh report of the Joint National Committee on Prevention, Detection, Evaluation and Treatment of High Blood Pressure. Hypertension 2003;42:1206-52. 
6. Julius S, Nesbitt SD, Egan BM, Weber MA, Michelson EL, Kaciroti N, et al.; Trial of Preventing Hypertension (TROPHY) Study Investigators. Feasibility of treating prehypertension with angiotensin-receptor blocker. N Engl J Med 2006;354:1685-97.

7. Vasan RS, Larsonmg, Leip EP, Evans JC, O’Donnell CJ, Kannel WB, et al. Impact of high-normal blood pressure on the risk of cardiovascular disease. N Engl J Med 2001;345:1291-7.

8. Qureshi AI, Suri MF, Kirmani JF, et al. Is prehypertension a risk factor for cardiovascular diseases? Stroke 2005;36:1859-63.

9. Paul S Jellinger, MD, MACE; Donald A Smith, MD, FACE; Adi E Mehta, MD, FRCP(C), FACE; Om Ganda, MD, FACE; Yehuda Handelsman, MD, FACP, FACE; Helena W Rodbard, MD, FACP, MACE; et al. American Association of Clinical Endocrinologists Medical Guidelines for Clinical Practice. The AACE Task Force for Management of Dyslipidemia and Prevention of Atherosclerosis. Endocrine practice vol 18 (suppl 1) Mar/April 2012.

10. Lenfant C, Chobanian AV, Jones DW, et al. Joint National Committee on the Prevention, Detection, Evaluation and Treatment of High Blood Pressure. Seventh report of the Joint National Committee on the Prevention, Detection, Evaluation and Treatment of High Blood Pressure (JNC 7): Resetting the hypertension sails. Hypertension 2003;41(6):1178-9.

11. Lauer RM, Clarke WR. Childhood risk factors for high adult blood pressure: The Muscatine Study. Pediatrics 1989;84(4):633-41.

12. Aghore Debbarma1, Himadri Bhattacharjya2*, Arpita Mohanty3, et al. International Journal of Research in Medical Sciences. 2015 May;3(5):1097-1101. Prevalence of pre-hypertension and its relationship with body mass index among the medical students of Agartala Government Medical College.
13. Mohit Shahi, Chow Wen Li. Pre-hypertension and its correlation with cardiovascular risk factors: a study among health sciences students in Malaysia. J Integrat Health Sci. 2013;1(2):104-9.

14. Shanthirani CS, Pradeepa R, Deepa R, Premalatha G, Saroja R, Mohan V. Prevalence and risk factors of hypertension in a selected South Indian population - the Chennai Urban Population Study. J Assoc Physicians India 2003;51:20-7.

15. Bao W, Threefoot SA, Srinivasan SR, et al. Essential hypertension predicted by tracking of elevated blood pressure from childhood to adulthood: The Bogalusa Heart Study. Am J Hypertens 1995;8(7):657-65.

16. Wu JS1, Lu FH, Yang YC, Lin TS, Chen JJ, Wu CH, et al. Epidemiological study on the effect of pre-hypertension and family history of hypertension on cardiac autonomic function. J Am Coll Cardiol. 2008 May 13;51(19):1896-901. doi:10.1016/j.jacc.2007.12.053.

17. Kavita Chaudhry, Sanjay Kumar Diwan, Mahajan SN. Pre-hypertension in young females, where do they stand? Indian Heart J 2012;6403:280-3.

18. Prehypertension among medical students and its association with cardiovascular risk factors journal of Dr. NTR University of Health Sciences Year: 2015 | Volume : 4 | Issue : 1 | Page: 8-12. Ravi Venkatachelam Chitrapu. ${ }^{1}$, Zeeshan Muzahid Thakkallapalli. ${ }^{2}$

19. Kaushika Rautray Student Sourya Acharya Samarth Shukla. A Study of the association of Abdominal Obesity, Dyslipidemia and Glycemic status in Pre-hypertensive Young Adults of a Medical University, Indian Medical Gazette April 2015. 